\title{
SYNERGY OF WASTE GLASS POWDER AND WASTE RUBBER: A RESEARCH ON LOADING, PERSEVERANCE AND MORPHOLOGICAL FEATURES OF UNBURNT FLY-ASH-BASED MASONRY UNITS
}

\author{
SINERGIJA ODPADNEGA STEKLENEGA PRAHU IN ODPADNE \\ GUME: RAZISKAVA OBREMENITEV, OBSTOJNOSTI IN \\ MORFOLOŠKIH ZNAČILNOSTI ZIDNIH ENOT NA OSNOVI \\ NEZGORELEGA DIMNIŠKEGA PEPELA
}

\author{
Selvaraj Praburanganathan*, Sarangapani Chithra \\ Department of Civil Engineering, Government College of Technology, Coimbatore, Tamil Nadu 614013, India \\ Prejem rokopisa - received: 2019-07-15; sprejem za objavo - accepted for publication: 2019-08-18
}

doi: $10.17222 /$ mit.2019.142

In the current context of the construction sector, the prospect and promotion of diverse industry and municipal waste-based materials are affianced to advance eco-friendly and more sustainable products. With this motto, the study aimed to investigate the synergistic effects of utilizing the crumb rubber from discarded waste tyres and finely ground glass powder from municipal waste glass in the production of unburnt bricks engaging a uniaxial pressing technique. The experiments conducted by mixing the rubber aggregates at 0-25\% with the stone dust and glass powders were blended with $0-25 \%$ with the fly ash. The fly ash and stone dust volumes were fixed as $60 \%$ and $25 \%$. The elemental composition of the raw materials and the morphology were studied using EDS and SEM. The physio-mechanical properties such as dry density, compressive strength, split tensile, modulus of rupture and perseverance studies such as water absorption, initial rate of absorption, capillary water-absorption coefficients using sorptivity study, efflorescence and direct UPV measurements evaluated and the results presented. In contrast to the earlier studies reported in the literature for the usage of rubber aggregates, the results of the current study reveal that the usage of rubber aggregates synergistic with glass powder enhance the compressive strength, split tensile and modulus of rupture of 2 $\%, 11 \%$ and $16 \%$ for the substitute level of $10 \%$ of both the waste materials. The better correlation observed in direct UPV Measurements with compressive strength. The density of the final developed products shows an $11 \%$ reduced density for the optimum addition of both the materials leads to lightweight brick production. Saturated water absorption of the developed mixes were within the limits prescribed by Indian thresholds. The developed materials fulfill the requirement of Indian specifications to use as masonry units.

Keywords: brick, fly ash, glass powder, rubber

Glede na trenutne trende $\mathrm{v}$ gradbeništvu, pospeševanje ostale industrije in obilico odpadnih materialov, ki nastajajo v mestih, je potrebno najti in razvijati nove ekološko napredne in bolj trajnostno naravnane proizvode. Avtorji so s tem ciljem izvedli študijo in raziskavo sinergijskih učinkov uporabe zdrobljene gume iz odpadnih gum in fino mletega steklenega prahu iz odpadnega mestnega stekla v proizvodnji nežgane opeke z uporabo tehnike enoosnega stiskanja. Preizkuse so izvajali z mešanjem od $0 \%$ do $25 \%$ gumijastih agregatov, kamnitega in steklenega prahu ter od $0 \%$ do $25 \%$ dimniškega pepela. Delež dimniškega pepela in kamnitega prahu sta bila fiksna na $60 \%$ oz. $25 \%$. Elementarno sestavo vhodnih surovin in njihovo morfologijo so študirali z uporabo energijske disperzijske spektroskopije (EDS) in vrstičnega elektronskega mikroskopa (SEM). V članku avtorji predstavljajo oceno in rezultate fizikalno-mehanskih lastnosti, kot so: suha gostota, tlačna in cepilno-natezna trdnost, modul porušitve in študijo obstojnosti - absorpcija vode, začetna hitrost absorpcije, koeficienti kapilarne absorpcije vode, kristalizacije in direktnih meritev na osnovi ultra pulznih hitrosti (UPV). V primerjavi s predhodno objavljenimi raziskavami glede uporabe gumijastih agregatov, rezultati te študije kažejo, da njihova uporaba v sinergiji s steklenim prahom izboljšuje tlačno trdnost, cepilno-natezno trdnost, ter modul porušitve za $2 \%, 11 \%$ oz. $16 \%$ pri uporabi obeh odpadnih materialov v dodatkih po $10 \%$. Boljšo korelacijo pri tlačni trdnosti so dokazali z UPV-meritvami. Novo razviti, končni izdelki so lažji in njihova gostota je zmanjšana za $11 \%$ pri optimalnem dodatku obeh surovin, kar pomeni novo proizvodnjo lahkih opek. Absorpcija vode pri nasičenju razvitih mešanic je znotraj meja predpisanih $\mathrm{z}$ indijskimi standardi. Razviti materiali izpolnjujejo pogoje navedene $\mathrm{v}$ indijskih standardih za njihovo uporabo kot zidarske enote.

Ključne besede: opeka, dimniški pepel, stekleni prah, guma

\section{INTRODUCTION}

The construction industry is suffering from numerous threatening effects, which includes energy-intensive production process, cost escalation of materials, non-standardization of newer products and more predominantly

*Corresponding author's e-mail:

praburanganathan@yahoo.com (Selvaraj Praburanganathan) of scarce raw materials, which leads to sustainable issues. ${ }^{1}$ In addition, solid waste management is a societal problem that needs immediate attention. ${ }^{2,3}$ The wastes produced from various industries and society needs a viable alternate disposal solution not to pollute the environment.

Glass waste that derived from the metropolitan region has the potential to be utilized as a brick additive. ${ }^{4}$ The 
raw wastes obtained from society are finely ground to a particle size of $38-45 \mu \mathrm{m}$, and it contains higher silica content (70\% and above), the waste glass powder (WGP) can be used as alternative supplementary cementitious materials, and it is pozzolanic and even cementitious. ${ }^{5,6,7}$ Most of the earlier investigations reported in the literature were utilizing the glass powder in concrete products. In this attempt, Glass powder blended with potential supplementary cementitious material such as fly ash was tried in the production of bricks.

All over the world, the problem of discarding waste tyres is increasing day by day due to the increase in the number of vehicles on the road. The direct landfilling strategies, burning of tyres leads to environmental degradation. ${ }^{8-11}$ Due to non-biodegradable nature, the decomposition of wastes in the natural environment takes much time. ${ }^{11}$ Waste tyres after a cryogenic grinding ${ }^{12}$ process making crumb rubber were utilized in the study as rubberized aggregate blended with stone dust in place of fine aggregate.

Conventional brick production leads to the emission of larger amounts of $\mathrm{CO}_{2},{ }^{13}$ due to firing the bricks and use clay as the predominant raw material, which leads to sustainable issues. In order to take out these issues, in this attempt fly ash-based masonry units utilizing lime binder were manufactured, incorporating waste materials engaging uniaxial pressing techniques for the production. The compaction pressure has a very distinctive influence on the reaction between fly ash and lime. Based on an earlier study, a sharp reduction in free $\mathrm{CaO}$ took place at a compaction pressure of $200 \mathrm{~kg} / \mathrm{cm}^{2} .{ }^{14}$

The focus of the earlier studies has been on the utilization of rubberized aggregate (RA) self-reliantly in concrete products and less in masonry units. Until now, no research has been reported, to the best knowledge of the authors, on the combined effect of RA and WGP in the production of fly-ash-based masonry units, and hence the available literature is also scarce. This research investigated the synergistic effects of utilizing Waste glass powder and rubberized aggregate in the production of unburnt bricks. The physio-mechanical perseverance studies and microstructure characterization were investigated as per the American standards (ASTM C67-02) to understand the synergistic effect of waste products such as waste glass powder (WGP) and rubberized aggregates (RAs).

\section{EXPERIMENTAL PART}

\subsection{Materials}

Fly ash of type Class F obtained from Metter Thermal Power Plant, Tamil Nadu, India was used for the study. It was of the siliceous type and fulfilled the requirement of American Standard (ASTM C 618) ${ }^{15}$ and Indian Standard (IS 3812:2013) ${ }^{16}$ for Class F Pozzolana. Hydrated lime as per Indian Standard (IS 712:1984) ${ }^{17}$ was used. Waste glass powder (WGP) of size $40 \mu \mathrm{m}$
(WGP) obtained from one of the glass recyclers from the southern part of Tamil Nadu, India was used. Rubberized aggregate (RA) of size $1 \mathrm{~mm}$ (20 mesh size) obtained from M/s.Thatchina Rubber Industries, paramakudi, Tamilnadu, India. The specific gravity of the obtained crumb rubber is 1.09 , and the fineness modulus is 2.9 . Locally sourced gypsum of minimum purity $80 \%$ was used for the current study. Stone dust obtained from the local quarry was used. Energy-dispersive x-ray spectroscopy (EDS) was used to distinguish the components in the WGP and RA and are provided in Table 1. Figure 1 depicts the $\mathrm{N}_{2}$ adsorption plot of the ingredients used in the current study. It implies that the adsorption of WGP and RA comparatively lower than fly ash (FA) and stone dust (SD) due to the lower porosity of the waste materials.

\subsection{Mixture proportion and production}

A series of brick mixes with various amounts of WGP blended with fly ash, and various amounts of RA blended with stone dust (SD) were produced for testing. When the WGP was added, the volume of fly ash with WGP was reduced by the WGP volume (volume of WGP, expressed as a percentage of the volume of the mix) so that the fly-ash volume and WGP volume remain unchanged. In this series of brick mixes, the sum of the fly-ash volume and WGP volume was fixed at $60 \%$, and the WGP volume was varied among $(0,5,10,15,20$ and 25) $\%$. Therefore, at WGP volumes of $(0,5,10,15,20$ and 25$) \%$, the respective fly-ash volumes were fixed at $(60,55,50,45,40$ and 35$) \%$. On the other hand, the fine aggregate volume was fixed at $25 \%$ of the volume of the mix. The RA volumes were replaced with stone dust at a ratio of $(0,5,10,15,20$ and 25$) \%$. Hence at the RA volumes of $(0,5,10,15,20$ and 25$) \%$ the corresponding stone-dust volumes were $(25,20,15,10,5$ and 0$) \%$.The volumes of gypsum and lime were fixed constant for all the mixes as $12 \%$ and $3 \%$, respectively. Details of the brick formulations are presented in Table 2. Each brick

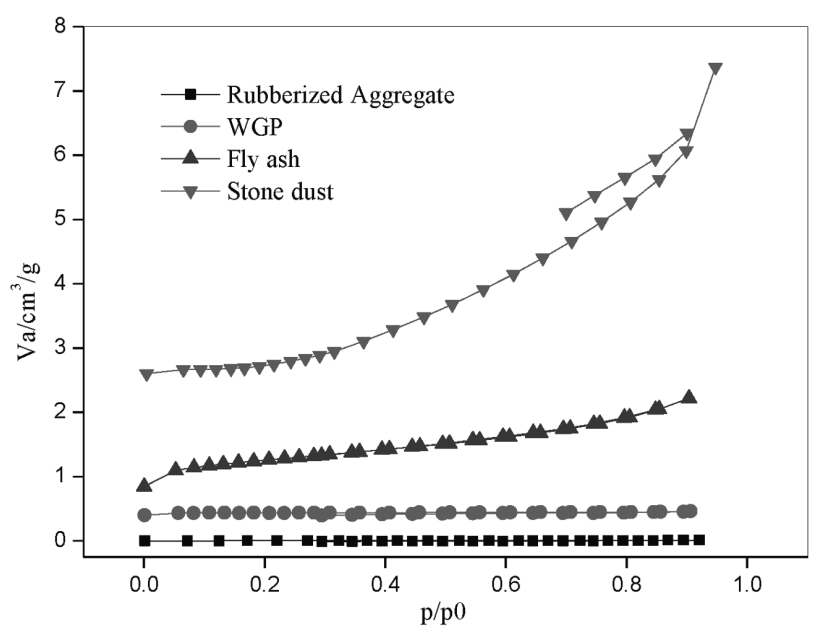

Figure 1: Nitrogen adsorption and desorption isotherm of ingredients 
S. PRABURANGANATHAN, S. CHITHRA: SYNERGY OF WASTE GLASS POWDER AND WASTE RUBBER ...

Table 1: Elemental composition of waste glass powder and rubberized aggregate

\begin{tabular}{|c|c|c|c|c|c|c|c|c|c|c|c|c|c|}
\hline Compounds & $\mathrm{Si}$ & $\mathrm{Na}$ & $\mathrm{Mg}$ & $\mathrm{Al}$ & $\mathrm{S}$ & $\mathrm{Cl}$ & $\mathrm{K}$ & $\mathrm{Ca}$ & $\mathrm{Fe}$ & $\mathrm{Cu}$ & $\mathrm{Zn}$ & $\mathrm{PdL}$ & $\mathrm{AuM}$ \\
\hline WGP & 77.12 & 8.59 & 1.88 & 0.36 & - & - & - & 5.09 & - & 0.51 & - & 1.13 & 5.32 \\
\hline RA & 34.95 & - & 1.34 & 0.98 & 6.79 & 3.94 & 0.27 & 14.17 & 1.43 & - & 12.98 & 4.86 & 18.29 \\
\hline
\end{tabular}

Table 2: Details of brick formulations

\begin{tabular}{|c|c|c|c|c|c|c|c|}
\hline \multirow[b]{2}{*}{ No } & \multirow[b]{2}{*}{ Mix ID } & \multicolumn{6}{|c|}{ Ingredients (\%) } \\
\hline & & Fly ash & Lime & Gypsum & Stone dust & $\begin{array}{c}\text { Rubberized } \\
\text { aggregate }\end{array}$ & $\begin{array}{c}\text { Waste glass } \\
\text { powder }\end{array}$ \\
\hline 1 & $\mathrm{CB}$ & 60 & 12 & 3 & 25 & - & - \\
\hline 2 & BWGPRA-5-5 & 55 & 12 & 3 & 20 & 5 & 5 \\
\hline 3 & BWGPRA-10-10 & 50 & 12 & 3 & 15 & 10 & 10 \\
\hline 4 & BWGPRA-15-15 & 45 & 12 & 3 & 10 & 15 & 15 \\
\hline 5 & BWGPRA-20-20 & 40 & 12 & 3 & 5 & 20 & 20 \\
\hline 6 & BWGPRA-25-25 & 35 & 12 & 3 & - & 25 & 25 \\
\hline
\end{tabular}

type was assigned a mix number A-B-C, in which A denotes the brick type with the names of brick type $\mathrm{CB}$ (control brick with no WGP and/or RA added) or BWGPRA (brick type of waste glass powder and rubberized aggregate were added as fly ash and stone-dust replacement). B denotes the blended volume of WGP with FA and C denotes the substitution volume of stone dust.

Bricks were prepared in a factory-controlled environment of size $230 \mathrm{~mm} \times 110 \mathrm{~mm} \times 75 \mathrm{~mm}$. The inter-granular contact was improved by the compaction pressure and thus easing the development of reaction by growing the creation of extra interfacial contact areas between the reactants. Nonetheless, a critical inter-particle gap or space is mandatory for the creation of diverse boundaries and the passage of the lime-bearing hydrated phases formed in the matrix. In the case of the higher magnitude of the compaction pressure, the gap is minimized, and it diminished the reaction rate. Hence the optimum formation pressure of $200 \mathrm{~kg} / \mathrm{cm}^{2}$ was maintained for the production of bricks. Initially, bricks were cured under a covered roof for $4 \mathrm{~d}$ and water sprinkled for $21 \mathrm{~d}$ and finally under dry curing for $3 \mathrm{~d}$.

\section{RESULTS AND DISCUSSION}

In this study WGP and RA incorporated bricks were examined in terms of their physio-mechanical, durability, and morphological properties.

\subsection{Physio-mechanical properties}

\subsubsection{Synergistic effects of WGP and RA on dry density:}

Figure 2 provides the test results for the dry density of developed brick specimens. It is noted that due to the incorporation of rubberized aggregates, the dry density of the specimens gradually decreased. All the developed brick types exhibit a dry density lower than the control mix. The maximum unit weight reduction of $11 \%$ occurs in the mix BWGPRA-25-25. The dry density of the developed bricks in the range $1480-1602 \mathrm{~kg} / \mathrm{m}^{3}$ was observed. These conclusions are in satisfactory agreement with earlier findings. ${ }^{18,19}$ It is noted that the incorporation of WGP and RA more than $10 \%$ provides a reduction in dry density values.

\subsubsection{Synergistic effects of WGP and RA on saturated water absorption:}

The addition of waste glass powder and rubberized aggregates improves the water absorption of the developed brick specimens. It was observed that $15 \%$ of WGP and RA provides comparatively lesser saturated water absorption values than other combinations. The developed bricks absorb 2-5\% more water than the control mix. The maximum absorption occurs at the $25 \%$ replacement of RA, which is the complete replacement of stone dust. Due to the softer nature of the rubber particles and the very fine powder particles of glass powder, it absorbs significantly more water than the control mix. As per Indian standards IS 13757:1993 and the ASTM-C67 standards, all the developed bricks shows water-absorption values lower than the stipulated values set out in the standards. Figure 2. shows the test values of the saturated water absorption of brick specimens immersed for $24 \mathrm{~h}$.

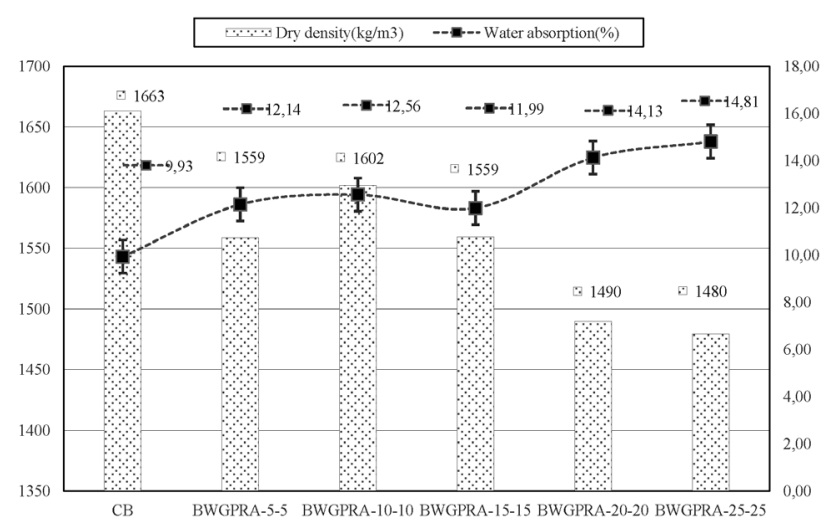

Figure 2: Synergistic effects of waste glass powder and rubberized aggregate on saturated water absorption and dry density 


\subsubsection{Synergistic effects of WGP and RA on the compressive strength:}

Figure 3 provides the test results for compressive strength at the ages of $(3,7,14$, and 28$) \mathrm{d}$. It is observed that the combined addition of $10 \%$ of WGP and $10 \%$ of RA provides an enhanced compressive strength over the control mix at the ages of 14 and $28 \mathrm{~d}$. The increase of WGP and RA gradually reduces the compressive strength values at all the ages. Up to the replacement level of $15 \%$ of GWP and RA provides the compressive strength that satisfies the minimum requirement set out in Indian Standards (IS3812:2013) to qualify as masonry units. It was noted that the complete replacement of $25 \%$ of RA with stone dust provides an extreme reduction in strength of $66 \%$ at the age of $28 \mathrm{~d}$. The reason was due to the generation of voids, which may be developed due to the fine nature of rubber particles ${ }^{20}$ and was verified using a morphology study.

\subsubsection{Synergistic effects of WGP and RA on split tensile strength}

Figure 4 Provides the Split tensile strength of developed brick specimens at the age of $7 \mathrm{~d}$ and $14 \mathrm{~d}$. The split tensile strength of $0.176-0.489 \mathrm{MPa}$ reported at the age of $28 \mathrm{~d}$. At the age of $14 \mathrm{~d}, 50-69 \%$ of the $28 \mathrm{~d}$ strength obtained by the developed brick specimens. At the age of 28 days the mixes BWGPRA-5-5, BWGPRA-15-15 BWGPRA-20-20 BWGPRA-25-25 obtained $16 \%, 8 \%, 25 \%$ and $60 \%$ reductions in strength compared to the control mix. The replacement of $10 \%$ of both the waste products shows enhanced split tensile strength at both the ages observed. All other combinations show a lower strength than the control mix without waste materials. The addition of WGP and RA of $10 \%$ provides $11 \%$ more strength than the control mix. Due to the lack of adhesion between the smooth rubberized aggregate and other ingredients may be the reason for the reduction in strength.

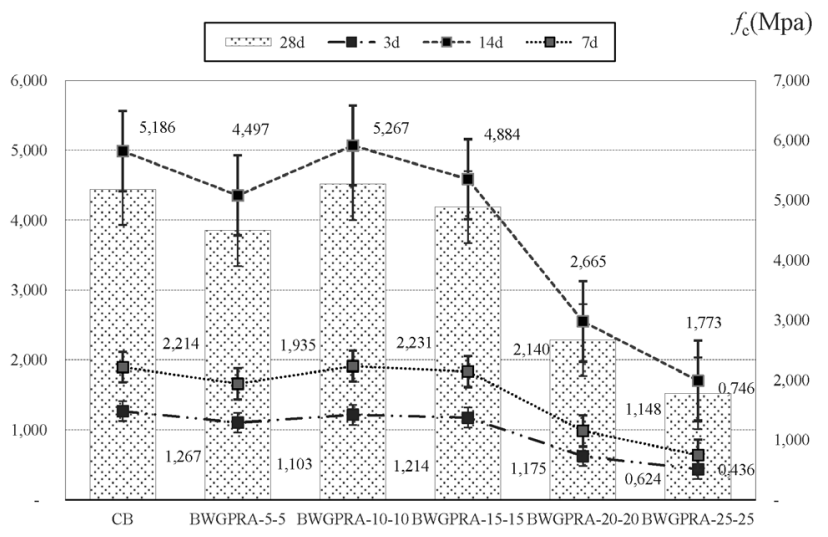

Figure 3: Synergistic effects of waste glass powder and rubberized aggregate on Compressive strength at various ages

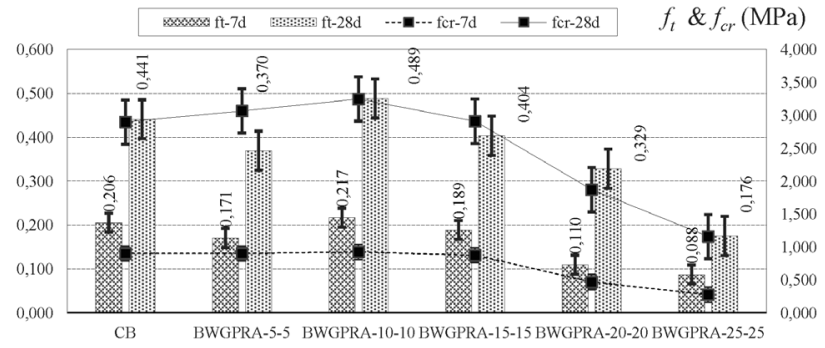

Figure 4: Synergistic effects of waste glass powder and rubberized aggregate on split tensile and rupture modulus at various ages

\subsubsection{Synergistic effects of WGP and RA on the modulus of rupture}

Unlike compressive and split tensile strength, the increased addition of WGP and RA provides the higher modulus of rupture than the control mix. The maximum flexural strength of a $16 \%$ higher value than the control mix was observed at the age of $28 \mathrm{~d}$ for the mix BWGPRA-10-10. The reason is that due to finely ground waste glass powder it exhibits a high pozzolanic reactivity. ${ }^{21}$ It is noted that the ingredients present in the brick facilitate the finer particles like waste glass powder to enter into the interstitial zones. The filling effect of the WGP occurs up to a certain extent of replacement only. ${ }^{20}$ This may be the reason for the rupture of the bond and the reduction in strength. Also, the development of cracks during the loading around the rubberized aggregate results in the rapid rupture of the brick specimens. Figure 4 provides the observation of the modulus of rupture. The variation of the modulus of rupture at both the ages when compared to the optimum mix provided in Figure 5.

\subsubsection{Synergistic effects of WGP and RA on direct UPV measurements}

The quality of the developed brick specimens evaluated using one of the popular non-destructive test methods such as ultrasonic pulse velocity. It was found that the incorporation of $10 \%$ of waste materials tends to increase the pulse velocity. For instance, for the $10 \%$ addition of WGP and RA increases the UPV from $1971 \mathrm{~m} / \mathrm{s}$ to $1993 \mathrm{~m} / \mathrm{s}$. For the complete replacement of stone dust for mix BWGPRA-25-25 by RA, the UPV values decreased from $1971 \mathrm{~m} / \mathrm{s}$ to $1675 \mathrm{~m} / \mathrm{s}$. In all the tested brick specimens the values were consistent with

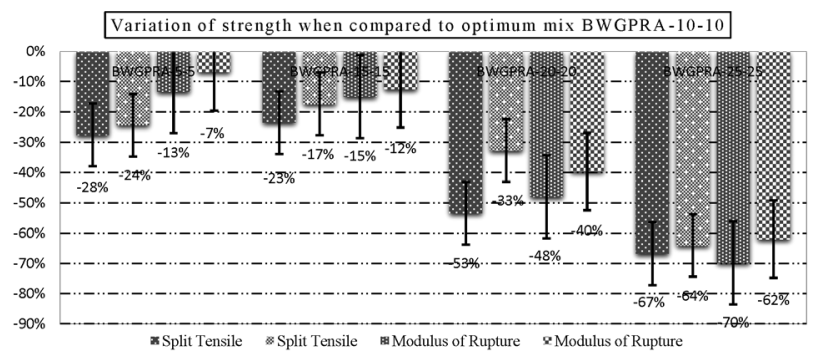

Figure 5: Variation of split tensile strength $f_{t}$ and modulus of rupture $f_{c r}$ when compared to optimum mix BWGPRA-10-10 


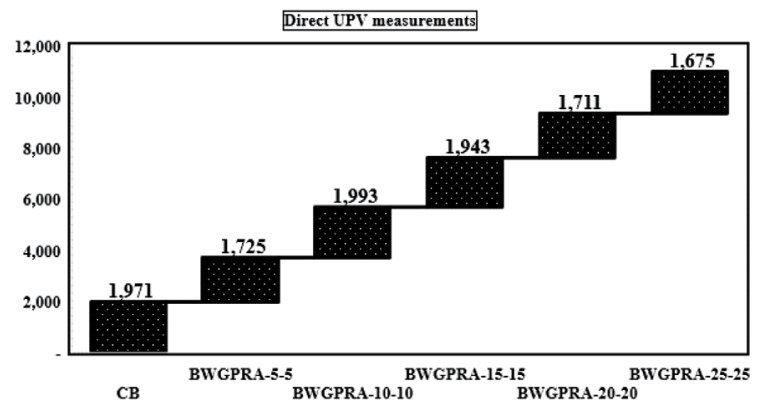

Figure 6: Synergistic effects of waste glass powder and rubberized aggregate on direct UPV measurements

Correlation of compressive strength Vs UPV

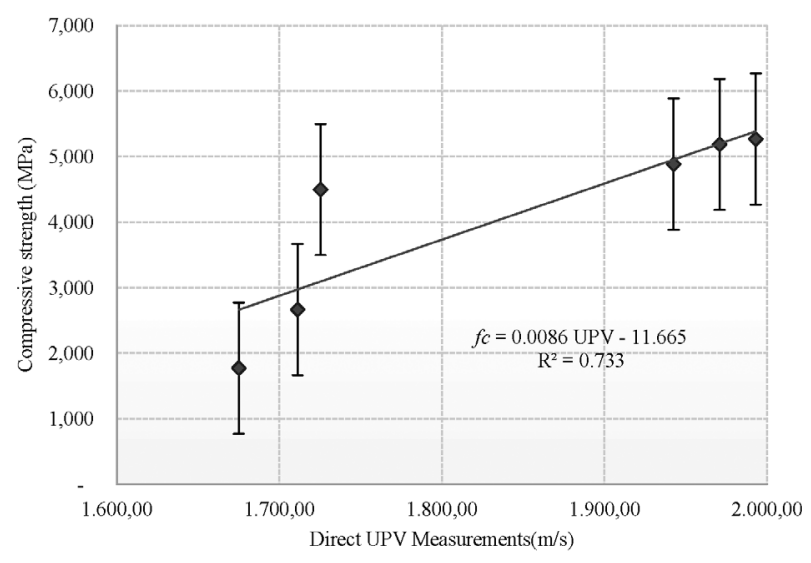

Figure 7: Correlation of compressive strength vs direct UPV measurements

the corresponding compressive strength observations. In general, the UPV and compressive strengths are directly proportional to each other. Figures $\mathbf{6}$ and $\mathbf{7}$ provide the direct UPV measurements and the correlation of the UPV and the compressive strength. In general, it is considered that if the UPV values are less than $1000 \mathrm{~m} / \mathrm{s}$ the bricks are not durable. ${ }^{22}$ In the current study, all the observations of UPV show values higher than $1000 \mathrm{~m} / \mathrm{s}$.

\subsection{Perseverance studies}

\subsubsection{Synergistic effects of WGP and RA on initial rate of absorption}

It is noted that there is no change in the initial rate of absorption for the $5 \%$ replacement of WGP and RA as the absorption is the same as that of the control mix. Up to $15 \%$ of the addition of WGP and RA minimizes the initial absorption values. Further additions from $20 \%$ to $25 \%$ tend to increase the initial rate of absorption characteristics of the developed brick specimens. Due to the soft nature of rubber and very fine particles of glass powder, the initial absorption may be increased after the addition of $15 \%$ of WGP and RA. The similar trend observed for the IRA-2 min for all the combinations. The IRA 1 min-values in the range of $0.80-2.83 \mathrm{~kg} \mathrm{~m}^{-2} \mathrm{~min}^{-1}$ and for IRA-2 $\min 1.23-3.36 \mathrm{~kg} \mathrm{~m}^{-2} \mathrm{~min}^{-1}$. It was reported that the absorption of clay bricks is in the range of $1.31 \mathrm{~kg} \mathrm{~m}^{-2} \mathrm{~min}^{-1}$ to $3.53 \mathrm{~kg} \mathrm{~m}^{-2} \mathrm{~min}^{-1}$. $^{23}$ Also, in the case of fly ash bricks, the absorption was reported as $6.3 \mathrm{~kg} \mathrm{~m}^{-2} \mathrm{~min}^{-1} .{ }^{24}$ When compared to other studies, the rubber and glass ash bricks and the slag ash bricks absorbed less water. The IRA test setup and stacked specimens provided in Figure 8 and Figure 9 provide the test set up and observation of the initial rate of absorption test results for the developed brick specimens.

\subsubsection{Synergistic effects of WGP and RA on sorptivity}

The sorptivity study was undertaken to evaluate the synergistic effects of waste glass powder and rubberized aggregate on the transport of water in bricks by capillarity, which is an indicator of the durability of the material. The sorptivity of brick specimens is presented in Figure 10. It was noted that the increased addition of WGP and RA tends to increase the sorptivity values considerably more than the contol mix. The addition of WGP and RA up to $15 \%$ produced a significant difference with the control mix. The addition of $5 \%$ and $15 \%$ of WGP and RA reduces the sorptivity by $20 \%$ and $31 \%$, respectively. This behaviour is due to the decrease of the porosity of the brick specimens up to
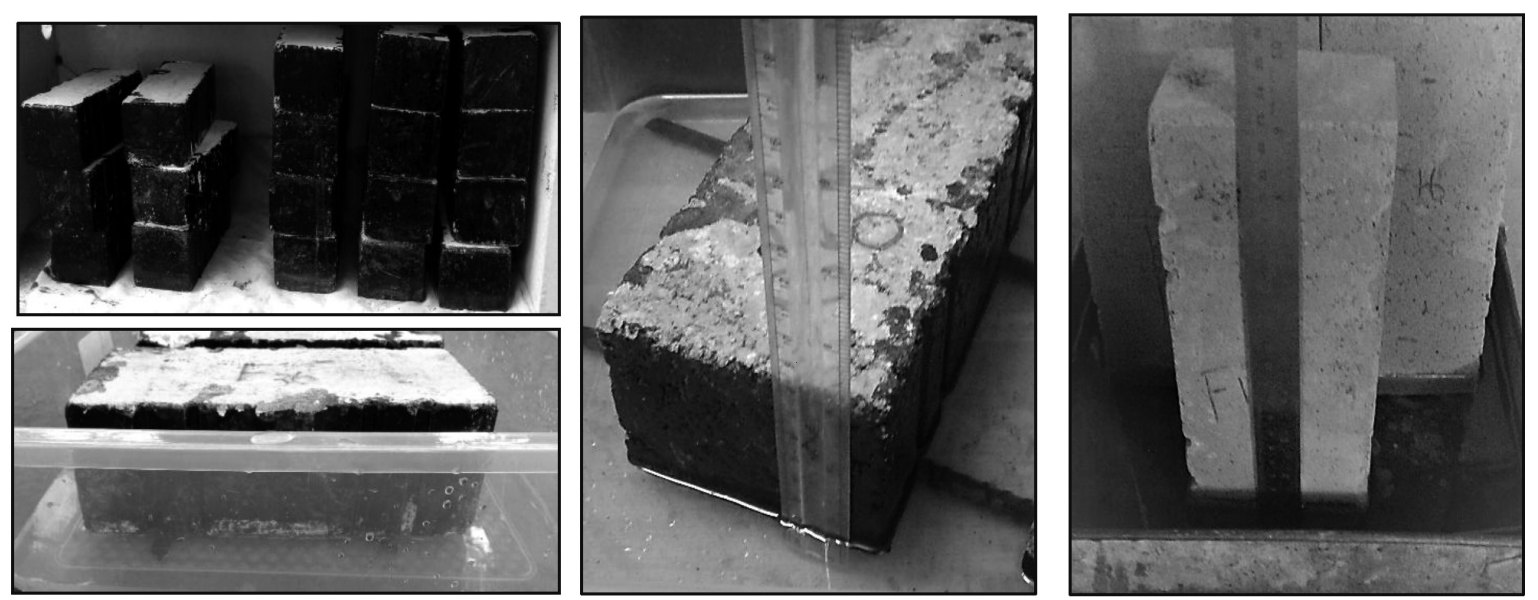

Figure 8: Specimens stacked after bitumen coating and test setup for IRA, sorptivity and efflorescence study 


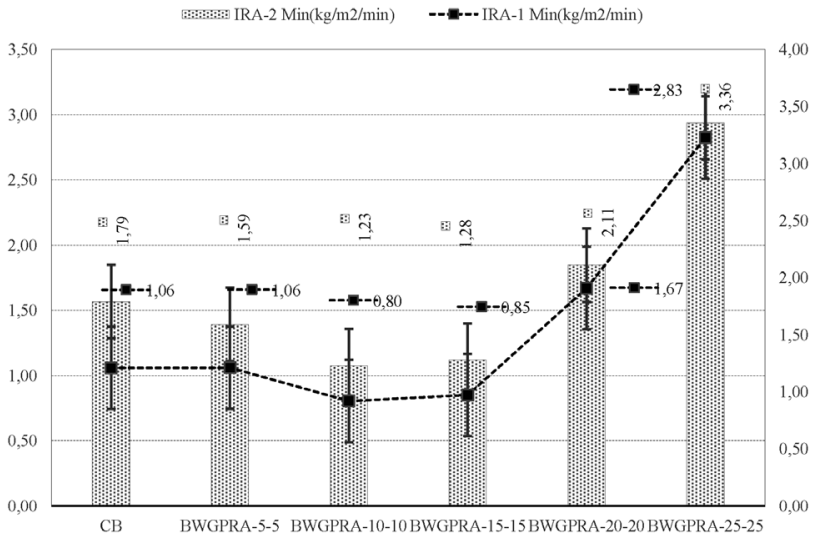

Figure 9: Synergistic effects of waste glass powder and rubberized aggregate on the initial rate of absorption

$15 \%$ addition, and any further increase tends to increase the porosity. The observation of the density matches with these findings. The sorptivity relates to the pore structure, which in turn influences the durability of the brick specimens.

\subsubsection{Synergistic effects of WGP and RA on efflorescence}

Efflorescence is an aesthetic problem due to the formation of foggy white deposits of salts on the brick specimen surfaces. It was observed after $7 \mathrm{~d}$. No efflorescence was observed both in control, and waste materials added specimens. Figure $\mathbf{8}$ depicts the specimen immersed in water for the efflorescence study. In general, calcium oxide plays a vital role in causing efflorescence. ${ }^{25}$ Comparatively, the fly ash has more $\mathrm{CaO}$ than WGP, and hence when it both blended, the calcium oxide gets reduced, which improves the efflorescence behaviour. Also, the Fe content in the WGP and RA as per chemical analysis shows $0 \%$ and $1.43 \%$, which are very minimal values and hence the possibility of efflorescence was a minimum when incorporating the waste materials.

\section{Sorptivity $\left(\mathrm{mm}^{\wedge} 3 / \mathrm{mm}^{\wedge} 2 / \mathrm{mm}^{\wedge} 0.5\right)$}

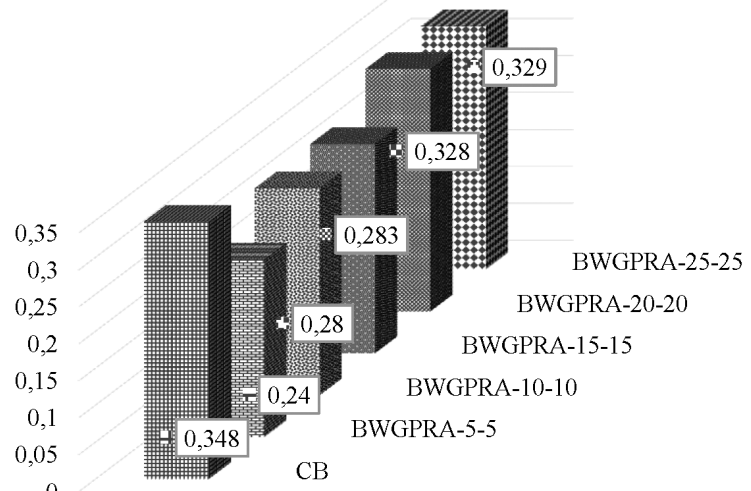

Figure 10: Synergistic effects of waste glass powder and rubberized aggregate on the capillary water absorption (sorptivity)

\subsection{Microstructural studies}

\subsubsection{Particle morphology of WGP and RA}

Figure 11a and 11b provide FESEM micrographs of the rubberized aggregate and the waste glass powder. The waste glass powder particles with their morphology shape show angular, clastic, and granular particles ${ }^{7}$. Due to finer particles, it provides a higher packing density and reduces the porosity of the hardened brick specimens. The rubber particles show weak compactness and a soft morphology. Due to the cryogenic process, the particles are not entirely round, and this shows as a loose feathered appearance.

\subsubsection{Synergistic effects of WGP and RA on the morphology of the optimum developed product}

Figure 11c to 11e provides the morphology of the Mix BWGPRA-10-10. Figure 11c clearly shows the fly ash particles and coated glass powder particles. The formation of C-S-H Gel as white patches was present. In some places the void spaces are visible. This may be due to the incompetent surface attraction of the rubberized particles with other ingredients. Figure 11d provides a micrograph that shows clearly the glass particles coated with rubber particles and shows a less dense matrix. Figure 11e depicts the open cell structure in the foam cross-section. Due to very fine powdery particles of glass

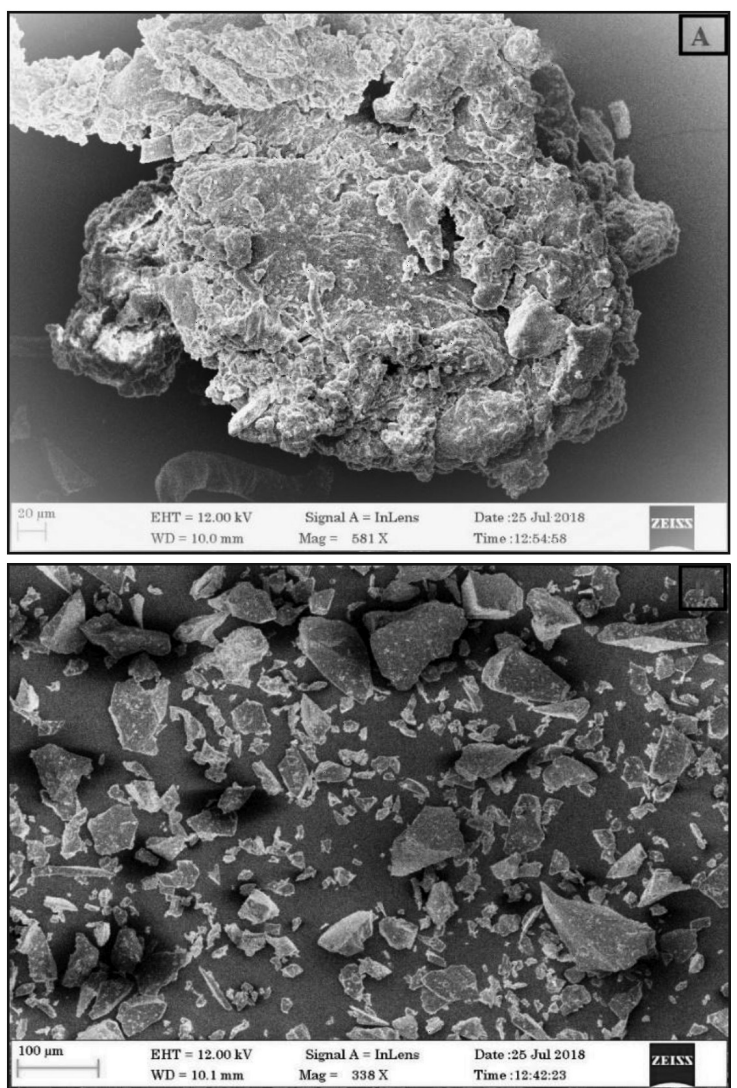

Figure 11: Morphology of: a) rubberized aggregate b) waste glass powder 

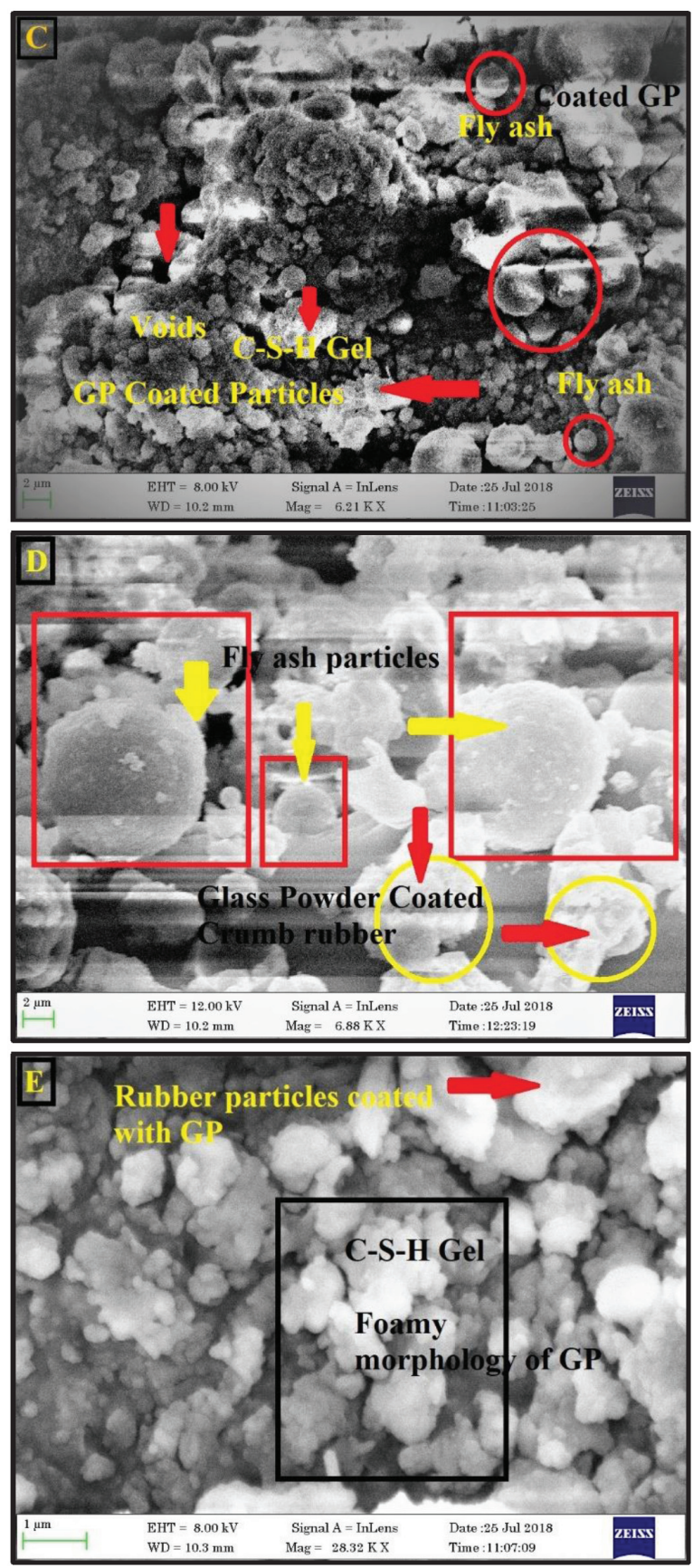

Figure 11: (C-E) Morphology of $10 \%$ of waste glass powder and $10 \%$ rubberized aggregate

powder, it can fill the pores, and it shows a relatively denser matrix, which may be the reason attributed for the enhanced strength at the optimum addition of WGP.

\section{CONCLUSIONS}

This assignment intended to study the synergistic effects of using rubberized aggregate and waste glass powder for the manufacturing of fly-ash-based bricks.
For this purpose, the effects of the combined utilization of WGP and RA on physio-mechanical and microstructural properties have been investigated. The main result showed that:

Modifications of bricks with rubberized aggregate significantly reduce the compressive strength of the specimens. The test result showed that the complete replacement of $25 \%$ of stoned dust by RA causes the compressive strength to drop by $66 \%$.

The synergistic effect of incorporation of glass powder together with Rubberized aggregate are advantageous in terms of increased compressive, split tensile and modulus of rupture of $2 \%, 11 \%$ and $16 \%$ for the addition of $10 \%$ of WGP. A higher contact was observed due to the higher surface area of fine particles of WGP, which facilitates the faster pozzolanic reaction. This may be the reason for the enhanced mechanical strength at the optimum WGP addition. This takes out the negative impact of using rubberized aggregate, which tends to minimize the strength values at all increments than the control mix, as stipulated in earlier literature of using rubberized aggregates independently.

The direct UPV measurements provide a consistent correlation with the corresponding compressive strength of the developed brick specimens.

The test result revealed that the saturated water absorption of the developed specimens is higher due to the addition of waste materials. However, this satisfies the Indian thresholds of maximum water absorption limits.

The modulus of rupture shows a $16 \%$ enhanced value compared to the control mix for the optimum mix BWGPRA-10-10 at the age of $28 \mathrm{~d}$.

The coefficient of capillary water absorption through the sorptivity study reveals that the increased addition of WGP and RA tends to increase the sorptivity, this sorptivity is related to the pore structure in turn. This relates to the durability performance of the bricks. Hence the optimum addition of WGP and RA relates to the durability performance, and is recommended to be not more than $15 \%$.

The limitations for the incorporation of the rubberized aggregate into bricks results from the increase of water absorption and also from the reduction of the mechanical strength. However, the result also suggests that the use of high concentration (above $10 \%$ ) of such waste into the brick body is not recommended, as it tends to decrease the mechanical strength.

The morphology of the waste glass particles shows an angular and dense structure compared to the rubberized aggregate, which provides a spongy and soft morphology and due to the fine particles of WGP it can fill up the pores and improves densification, which in turn is the reason for the enhanced mechanical strength at the optimum addition. 


\section{REFERENCES}

${ }^{1}$ Y. Aggarwal, R. Siddique, Microstructure and properties of concrete using bottom ash and waste foundry sand as partial replacement of fine aggregates, Construction and Building Materials 54 (2014) 210-223, doi:10.1016/j.conbuildmat.2013.12.051

${ }^{2}$ A. Ali Aliabdo, M. Abd Elmoaty Abd Elmoaty, M. Mostafa Abd Elbaset, Utilization of waste rubber in non-structural applications, Construction and Building Materials, 91 (2015), 195-207, doi:10.1016/j.conbuildmat.2015.05.080

${ }^{3}$ N. Sudharsan, T. Palanisamy, Feasibility of using waste glass powder in fly ash bricks, International Journal of Advanced Engineering Technology, (2016) E-ISSN 0976-3945

${ }^{4}$ N. Phonphuak, S. Kanyakam, P. Chindaprasirt, Utilization of waste glass to enhance physical-mechanical properties of fired clay brick, Journal of Cleaner Production., 112 (2016), 3057-3062, doi:10.1016/j.jclepro.2015.10.084

${ }^{5}$ V. Matte, M. Moranville, F. Adenot, C. Riche, J. M. Torrenti, Simulated microstructure and transport properties of ultra-high performance cement-based materials, Cement and Concrete research, 30 (2000) 12, 1947-1954, doi:10.1016/S0008-8846(00)00288-X

${ }^{6}$ Y. Shao, T. lefort, S. Moras, D. Rodriques, Studies on concrete containing ground waste glass, Cement and Concrete research, 30 (2000) 1, 91-100, doi:10.1016/S0008-8846(99)00213-6

${ }^{7}$ S. Liu, Q. Li, G. Xie, L. Li, H. Xiao, Effect of grinding time on the particle characteristics of glass powder, Powder Technology, 295 (2016) 133-141, doi:10.1016/j.powtec.2016.03.030

${ }^{8}$ T. S. Blessen, R. C. Gupta, V. J. Panicker, Recycling of waste tyre rubber as aggregate in concrete: durability related performance, Cleaner Production, 112 (2015) 504-513, doi:10.1016/j.jclepro. 2015.08.046

${ }^{9}$ A. Benazzouk, O.Douzane,T. Langlet, K. Mezreb, J.M. Roucoult, M. Queneudec, Physico-mechanical properties and water absorption of cement composite containing shredded rubber wastes, Cement and Concrete Composites, 29 (2007) 732-740, doi:10.1016/ j.cemconcomp.2007.07.001

${ }^{10}$ T. S. Blessen, R. C. Gupta, P. Mehra, Sanjeev Kumar, Performance of high strength rubberized concrete in an aggressive environment, Construction and building materials, 83 (2015) 320-326, doi:10.1016/j.conbuildmat.2015.03.012

${ }^{11}$ G. Girskas, D. Nagrockiene, Crushed rubber waste impact of concrete basic properties, Construction and building materials, 140 (2017) 36-42, doi:10.1016/j.conbuildmat.2017.02.107

${ }^{12}$ F. Azevedo, F. Pacheco-Torgal, C. Jesus, J. L. Barroso de Aguiar, A. F. Cameos, Properties and durability of HPC with tyre rubber wastes, Construction and Building Materials, 34 (2012) 186-191, doi:10.1016/j.conbuildmat.2012.02.062
${ }^{13}$ L. Anant Murmu, A. Patel, Towards sustainable bricks production: An overview, Construction and Building Materials, 165 (2018) 112-125, doi:10.1016/j.conbuildmat.2018.01.038

${ }^{14}$ A Basumajumdar, A. K. Das, N Bandyopadhyay, S Maitra, Bulletin of Material Science, Indian Academy of Sciences, 28 (2005) 2, $131-136$.

${ }^{15}$ ASTM C 618 Standard Specification for Coal Fly Ash and Raw or Calcined Natural Pozzolan for Use in Concrete, ASTM International, PA,2019

${ }^{16}$ IS3812:2013, Indian Standard Pulverized Fuel Ash-Specification, Bureau of Indian Standards, New Delhi

${ }^{17}$ IS 712-1984, Indian Standard Specification for building Limes, Bureau of Indian Standards, New Delhi

${ }^{18}$ S. Bashar Mohammed, M. Khandaker Anwar Hossain, Jackson Ting Eng Swee, G. Wong, M. Abdullahi, Properties of crumb rubber hollow concrete block, Journal of Cleaner Production 23 (2012), 57-67, doi:10.1016/j.jclepro.2011.10.035

${ }^{19}$ E. Sodupe-Ortega, E. Fraile-Garcia, J. Ferreiro-Cabello, A. Sanz-Garcia, Evaluation of crumb rubber as aggregate for automated manufacturing of rubberized long hollow blocks and bricks, Construction and Building materials, 106 (2016) 305-316, doi:10.1016/j.conbuildmat.2015.12.131

${ }^{20}$ K. Bisht, P. V. Ramana, Evaluation of mechanical and durability properties of crumb rubber concrete, Construction and building materials, 155 (2017), 811-817, doi:10.1016/j.conbuildmat. 2017.08.131

${ }^{21}$ N. Sudharshan, T. Palanisamy, C. Subhash Yaragal, Environmental sustainability of waste glass as a valuable construction material - A critical review, Ecology Environment \& Construction, 24 (2018), S335-S342

${ }^{22}$ S. R. Koroth, P. Fazio, D. Feldman, Evaluation of clay brick durability using ultrasonic pulse velocity, Journal of Architectural Engineering, 4 (1998), 142-147

${ }^{23}$ G. Sarangapani, B. V. Venkatarama Reddy, K. S. Jagadish, Brickmortar bond and masonry compressive strength, Journal of Materials in Civil Engineering, 17(2005) 2, 229-238, doi:10.1061/ (ASCE)0899-1561(2005)17:2(229)

${ }^{24}$ C. Freeda Christy, R. Mercy Shanthi, D. Tensing, Bond strength of the brick masonry, International Journal of civil Engineering and Technology, (2012)

${ }^{25}$ M. S. Syed Kazmi, S. Abbas, A. Muhammad Saleem, J. Muhammad Munir, A. Khitab Manufacturing of sustainable clay bricks: Utilization of waste sugarcane bagasse and rice husk ashes, Construction and Building Materials, 120 (2016), 29-41, doi:10.1016/ j.conbuildmat.2016.05.084 